\title{
MODELLING AND SIMULATION CHARACTERISTICS OF STARTING SYSTEM
}

\section{MODELOWANIE I SYMULACJA CHARAKTERYSTYK OBWODU ROZRUCHOWEGO}

\author{
Mieczysław Dziubiński ${ }^{1)}$, Mieczysław Plich ${ }^{2)}$, Artur Drozd ${ }^{1)}$ \\ ${ }^{1)}$ Lublin University of Technology, Faculty of Mechanical Engineering \\ ${ }^{2)}$ Warsaw Univerisity of Technology Faculty of Transport \\ m.dziubinski@pollub.pl
}

\begin{abstract}
The main purpose of the work was to develop the analytical simulation model for the starting system and to verify it on the real object. The reliability analysis of the starting system connected with operating use of mechanical and electric elements has been carried out in the developed model. It was a novelty in the conducted examination to use the LabView software for the registration of electric signals (current and voltage) and mechanical ones (rotational speed and torque).
\end{abstract}

Keywords: starting system, modelling, reliability

Streszczenie: Gtównym celem pracy było opracowanie analitycznego modelu symulacyjnego dla obwodu rozruchowego oraz weryfikacja na obiekcie rzeczywistym. $\quad W$ opracowanym modelu przeprowadzono analize niezawodnościowa ukladu rozruchu zwiąana $z$ eksploatacyjnym zużyciem elementów o charakterze mechanicznym $i$ elektrycznym. Nowościa $w$ przeprowadzonych badaniach byto wykorzystanie oprogramowania LabView do rejestracji sygnatów elektrycznych (prąu $i$ napięcia) oraz mechanicznych prędkości obrotowej i momentu obrotowego.

Stowa kluczowe: obwód rozruchowy, modelowanie, niezawodność 
Modelling and simulation characteristics of starting system

Modelowanie i symulacja charakterystyk obwodu rozruchowego

\section{MODELLING AND SIMULATION CHARACTERISTICS OF STARTING SYSTEM}

\section{Introduction}

Problems with identification of failures in particular systems occur in the course of car operation. In order to determine them, diagnostic investigation is conducted with the use of the OBD system - deck diagnostics and detailed measurements including: measurement of compression pressure in cylinders and measurement of voltage and amperage of the current taken by the starter [7]. In case malfunction of a given system is stated, detailed measurements are conducted. In order to predict the condition of malfunction, simulation models enabling to forecast the state of a chosen system e.g. an electric one, are developed, and verification is conducted on a real object $[1,3,4,5]$.

The starter constitutes an essential element of a car engine. Its failure-free work directly influences the correct work of the starting system. Functional diagnostics makes it possible to recognize the type of failure in the starter. The developed program is used to determine functional characteristics of the starter. It enables the analysis of the influence of chosen failures on starter characteristics.

\section{Reliability model of the starter}

The theoretical model was developed on the basis of start-up system equations $[2,6,8,9,10]$. Figure 1 presents the diagram of start-up circuit connections in which characteristic electric values are indicated. It can be concluded from the figure that voltage $U R$ on the clamps of the starter in steady state can be calculated by summing drops in voltage (1):

$$
U_{R}=E_{A}-\left(R_{w}+R_{p}\right) I
$$

where:

$E_{A}$ - battery electromotive force,

$R w$ - battery interior resistance,

$R p$ - resistance of conductors connecting the starter and the battery,

$I$ - current taken by the battery.

Counter-electromotive force can be expressed by the following formula (2):

$$
E_{R}=U_{R}-\Delta U_{S Z}-R_{R} \cdot I
$$

Considering the state of full braking $\left(\mathrm{n}=0, E_{R}=0\right)$, it is possible to determine the value of current taken from the battery at start-up ( fault current I) (3):

$$
I=\frac{E_{A}-\Delta U_{S Z}}{R_{w}+R_{p}+R_{R}}=I_{Z}
$$




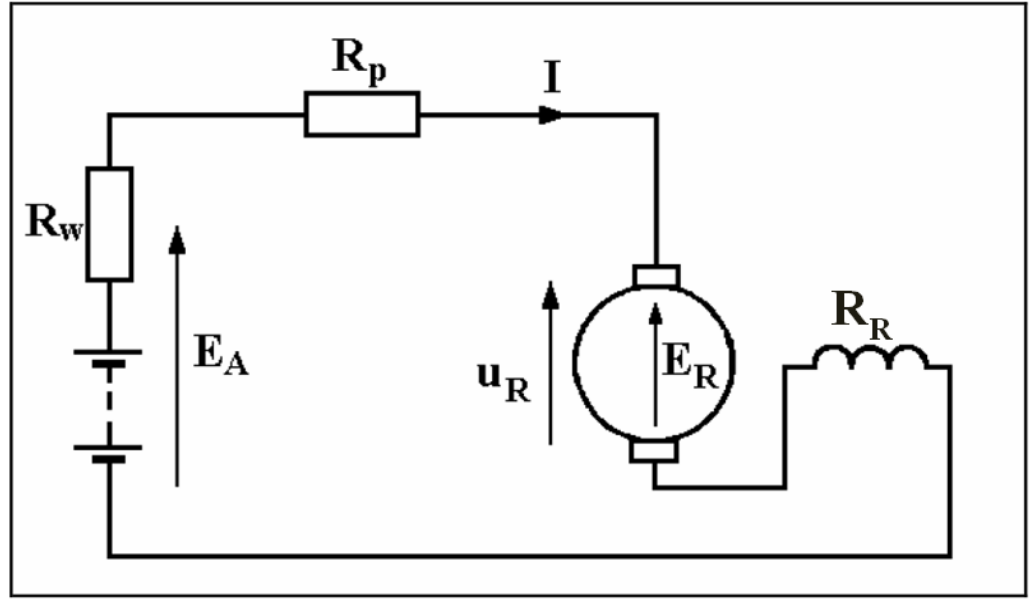

Fig.1. Connection diagram of the start-up circuit in which characteristic values are indicated $\left(E_{A}\right.$ - electromotive force, $R_{W}$ - battery interior resistance,

$$
\begin{aligned}
& R_{p} \text { - resistance of conductors, } U_{R} \text { - voltage on the starter, } \\
& E_{R} \text { - counter-electromotive force, } R_{R} \text { - starter resistance) }
\end{aligned}
$$

The power of the starter is expressed by the following formula (4):

$$
P_{e}=E_{R} I=\left(E_{A}-\Delta U_{S Z}\right) I-\left(R_{w}+R_{p}+R_{R}\right) I^{2}
$$

The power value equals zero in two points: an initial one (where $E_{R}=0$ i $n=0$ ) and in the point of work corresponding to the theoretical no-load state $(\mathrm{I}=0)$.

The current at which electromagnetic power reaches its maximum value can be determined from the following relation (5):

$$
I_{p \max }=\frac{E_{A}-\Delta U_{S Z}}{2\left(R_{w}+R_{p}+R_{R}\right)}=\frac{I_{z}}{2}
$$

The maximum power of the starter is determined by substituting the current from the formula to the relation (5):

$$
P_{\text {max }}=\frac{\left(E_{A}-\Delta U_{S Z}\right)^{2}}{4\left(R_{w}+R_{p}+R_{R}\right)}
$$

The starter electromagnetic efficiency is assumed $-\eta e=0,85-0,9$ - formula 7 :

$$
P_{R}=P_{e} \eta_{e}
$$

The statement of starter modeled characteristics is presented in fig. 2 . 
Modelling and simulation characteristics of starting system

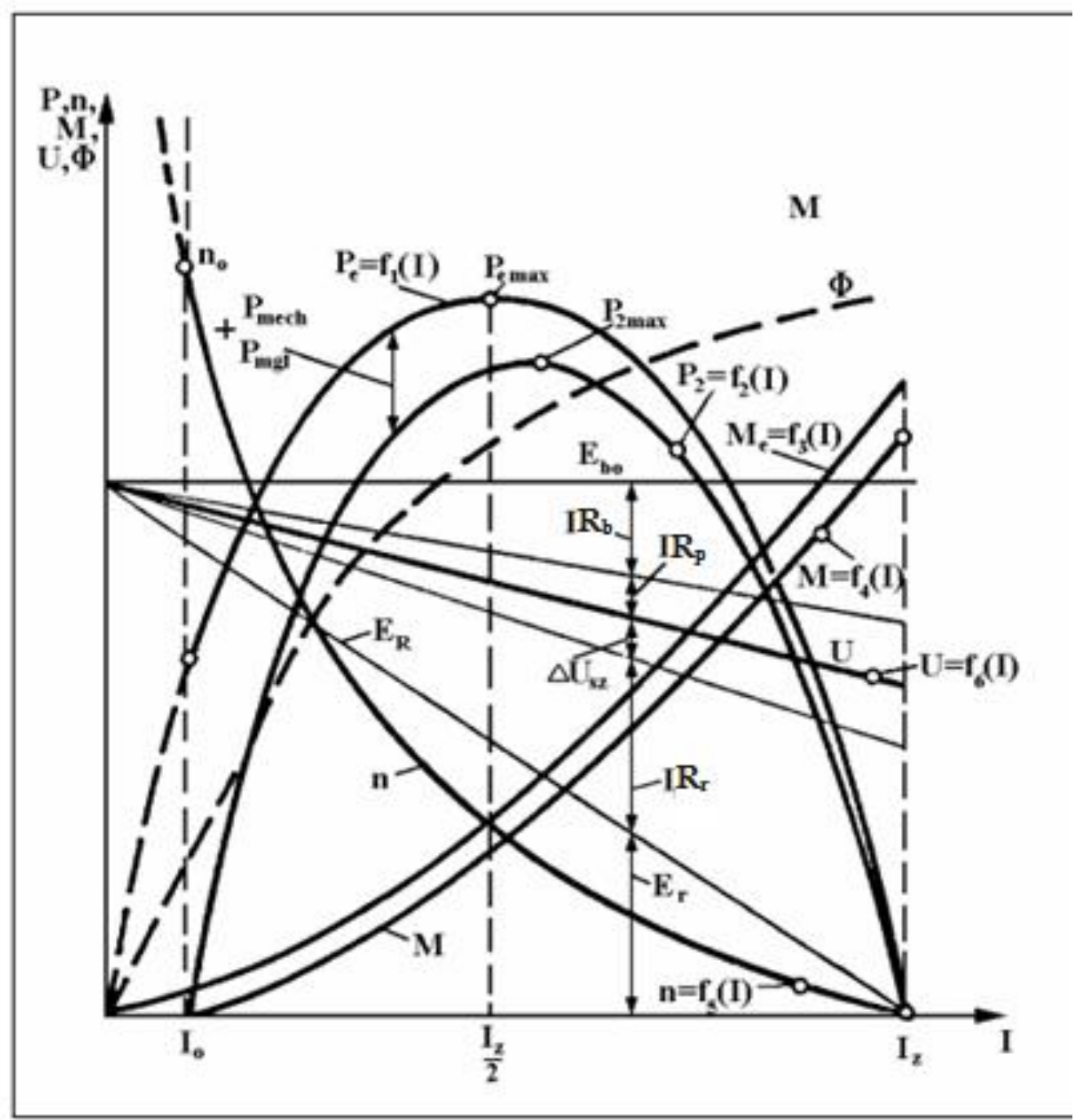

Fig.2. Characteristics of the car starter $(P$ - power, $n$ - rotational speed, $M$ - starter torque, $U$-voltage, $\phi$ - magnetic flux, $E_{R}-$ starter counterelectromotive force, $I_{Z}$ - fault current ).

In order to analyse the influence of failures on functional characteristics of starters, one should do calculations, choosing the type of the starter, material of the pole and the yoke, material of the metal sheet of the rotor and the kind of failure (Fig. 3) and entering basic data of the starter according to fig. 4. For the selected kind of failure, the program determines characteristics for the starter in working order, as well as for a given type of failure on one graph (Fig. 5). 


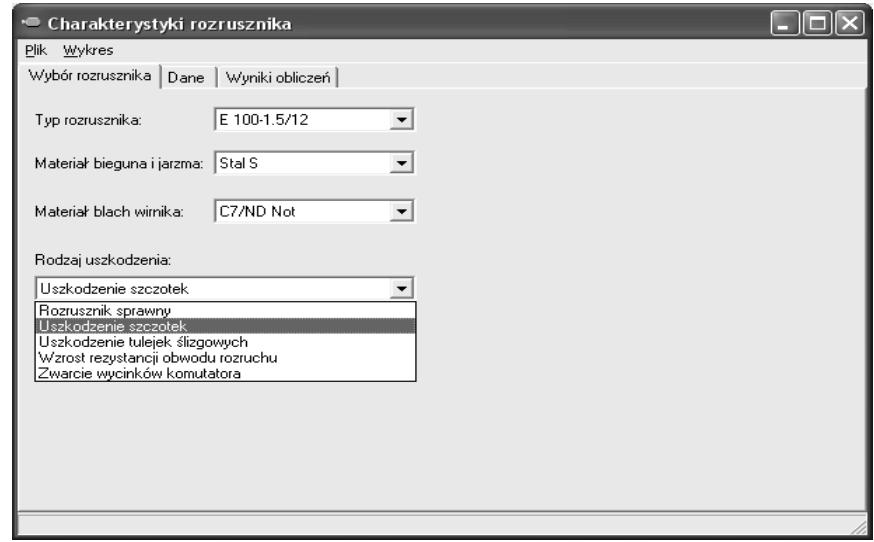

Fig.3. Selection of basic functions of the program

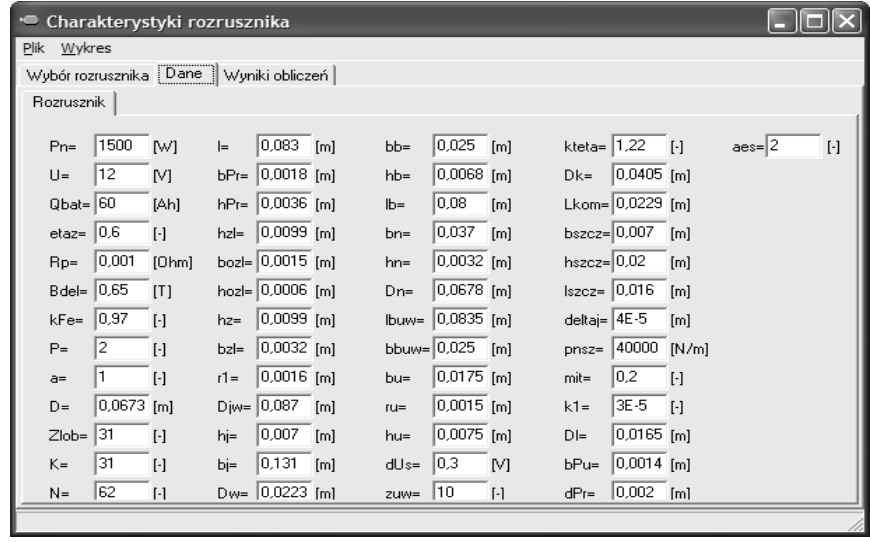

Fig.4. Basic data of E100 starter

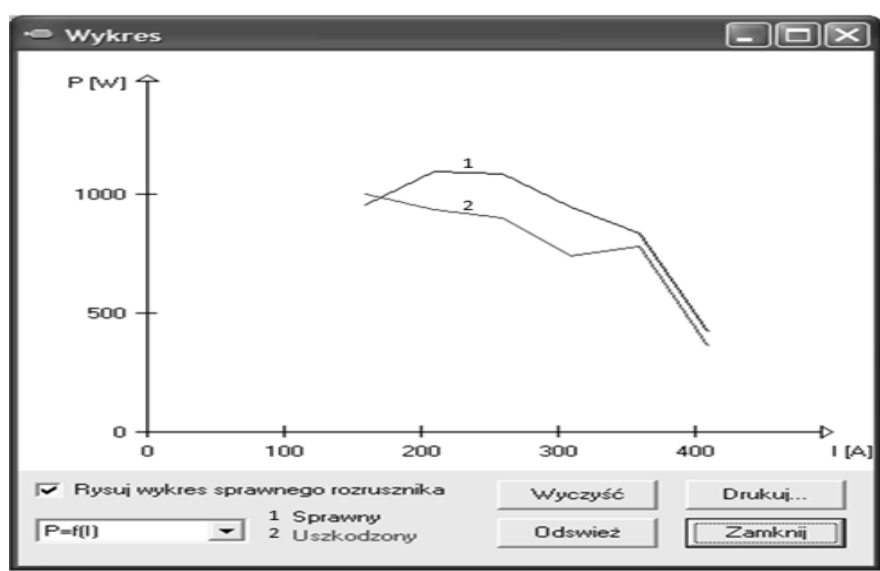

Fig.5. Characteristic $P=f(I)$ at brush damage ( 1 -effcient, 2 - demaged $)$ 
Modelling and simulation characteristics of starting system

Modelowanie i symulacja charakterystyk obwodu rozruchowego

\section{Simulation tests of failures performed on real objects}

The tests were carried out on the Bosch EFAL 50A/ 5 testing bench which enables conducting the process of starter braking and the registration of current taken by the starter, voltage drop during the start-up, current taken by the starter while braking, voltage drop while braking, the rotational speed of the starter and the torque of the starter. The registration of results was conducted with the use of Adlink Technology Inc. USB-1900 Series apparatus with the LabView software (Fig.7).

On the testing bench the following failures in the start-up circuit were simulated:

- Failure 1: lack of connection between the excitation winding and the first positive brush

- Failure 2: lack of connection between the excitation winding and the second positive brush

- Failure 3: break in the excitation winding and the shunt winding

- Failure 4: failure in the shunt winding

- Failure 5: lack of connection between the frame and the negative brush

- Failure 6: shorting between the commutator bars

- Failure 7: shorting of two pairs of commutator bars

- Failure 8: battery discharge

- Failure 9: excessive clearance in the disk sliding sleeve

- Failure 10: excessive clearance in the head sliding sleeve

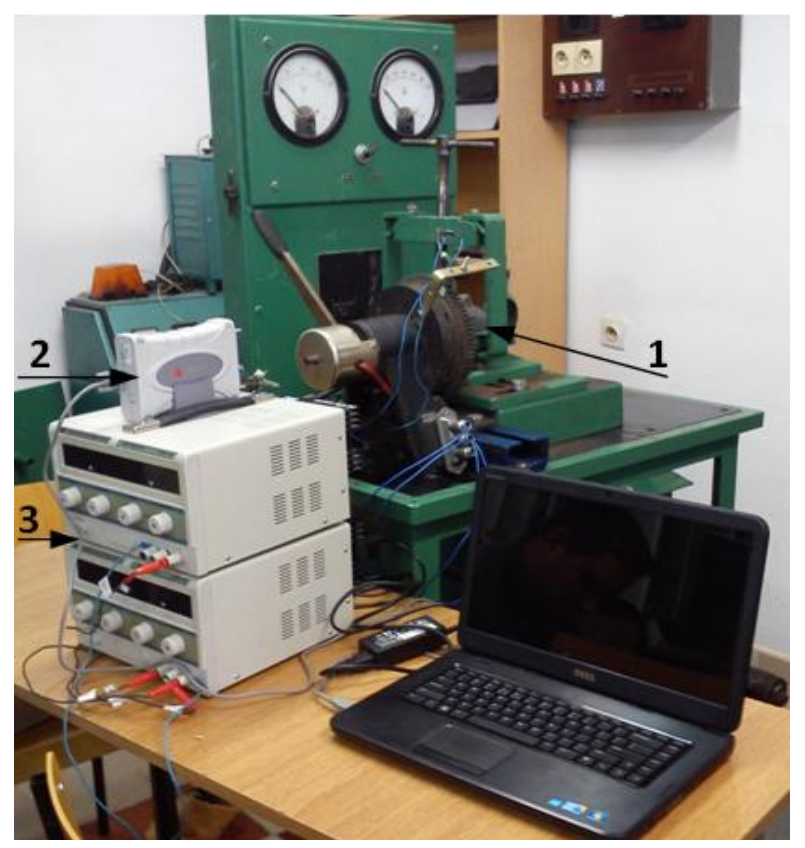

Fig.6. Bench for testing nonstationary states of start-up systems (1-tested starter, 2 -transducer, 3 - feeders) 


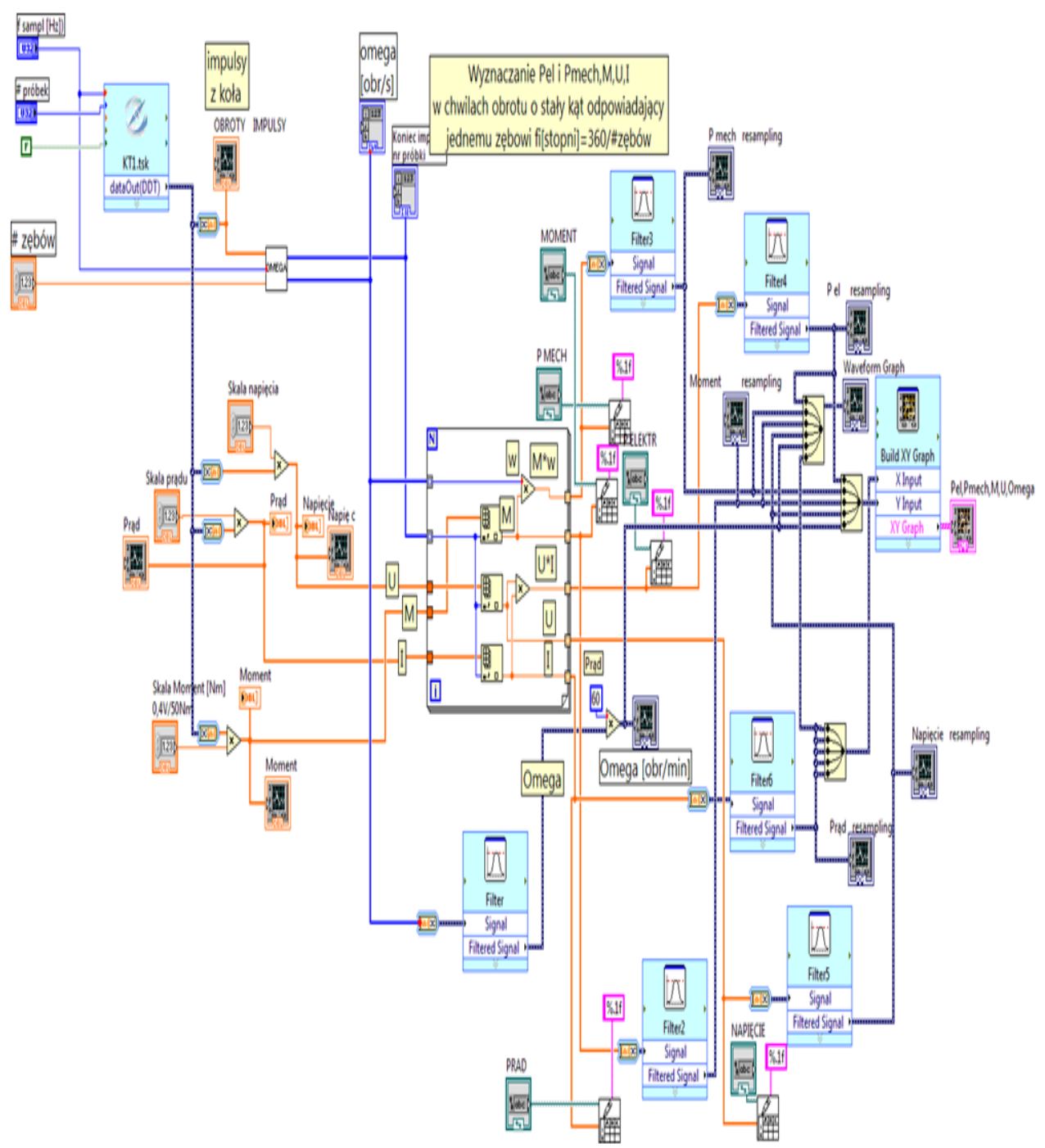

Fig.7. Diagram of the algorithm for determining starter characteristics

Fig.8 and 9 present current and voltage courses in the function of time for chosen failures. The failures were simulated by disconnecting the terminal from the brush „+". It can be concluded from Fig.8 that maximum current value equals $655 \mathrm{~A}$ and was lower than current value for the properly working starter. In the final stage of start-up, i.e. after $107 \mathrm{~ms}$, the current value in the starter reached 378A, which means the increase in current value by $50 \%$ against the properly working starter. 
Modelling and simulation characteristics of starting system Modelowanie i symulacja charakterystyk obwodu rozruchowego

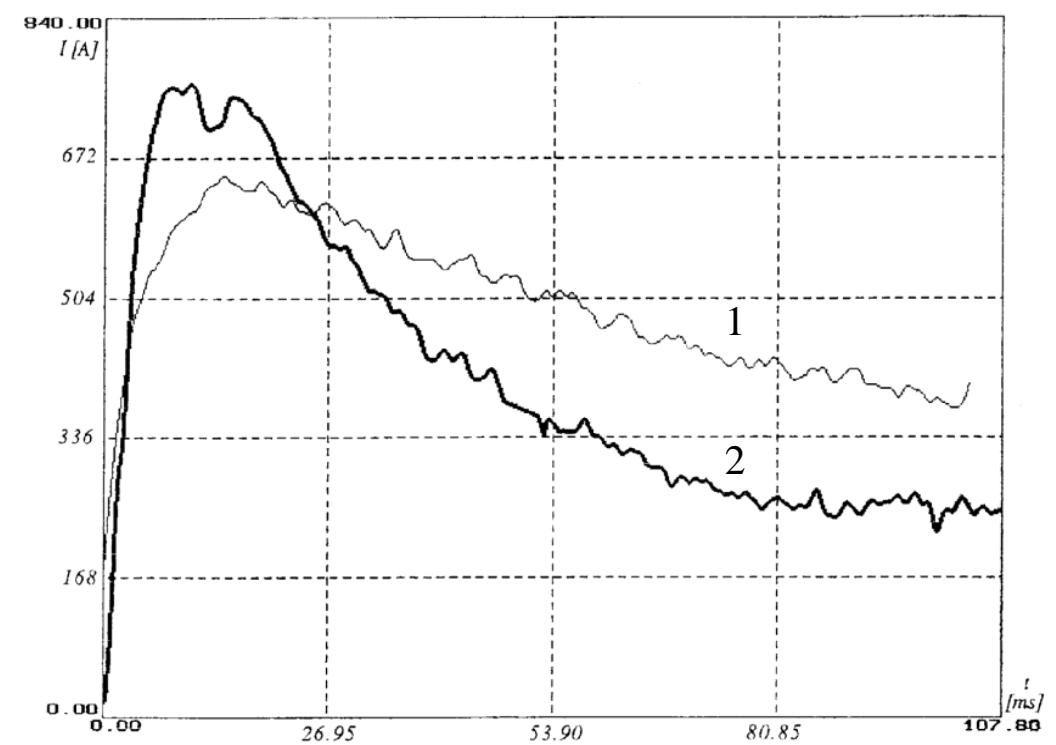

Fig.8. Characteristic $I=f(t)$ at excitation winding disconnected from the first positive brush (1-damaged, 2 - efficient)

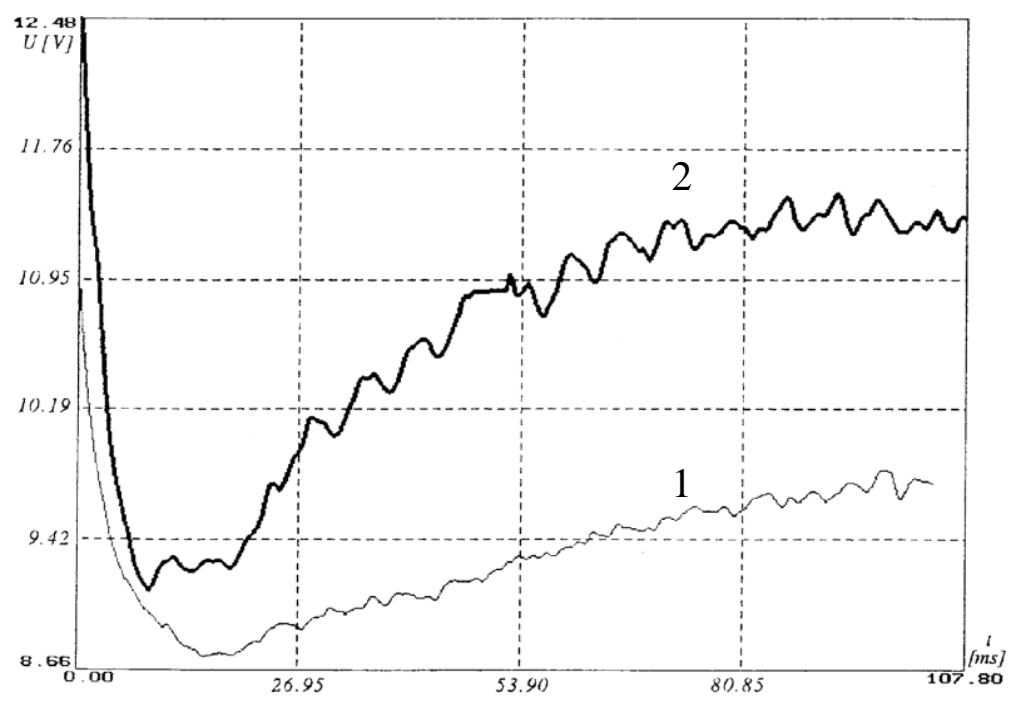

Fig.9. Characteristic $U=f(t)$ at excitation winding disconnected from the first positive brush (1-damaged, 2 - efficient)

Fig.10 presents the characteristic of the simulated failure which is the lack of connection between excitation winding and the first positive brush. It can ce concluded from the picture that in case of failure the power is much smaller than in a properly working starter and reaches the maximum value of $613 \mathrm{~W}$. 


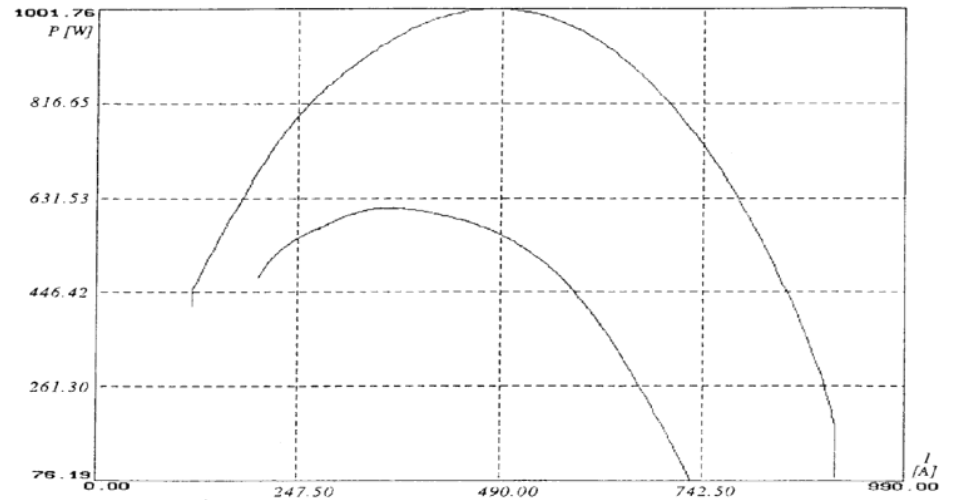

Fig.10. Function $P=f(I)$ at the lack of connection between excitation winding and the first positive brush (1-damaged, 22-efficient)

\section{Conclusions}

The developed model of the starter makes it possible to simulate characteristics of the electric circuit of the starter. The registered results and signals enable analysing the influence of particular electric values on functional parameters of the start-up system. On the basis of the conducted examination, it can be stated that the characteristics of current and voltage registered during the experiment reflect the characteristics simulated on the model. The developed model and verification examination conducted on the real object make it possible to forecast the technical condition of the starter.

Determining the kind of failure results is possible from comparing characteristics power failures of starter with the maximum power developed by the starter. In failures such as the lack of connection between excitation winding and the first positive brush the power is $60 \%$ smaller than in the case of the efficient starter. The developed method of starter reliability analysis is based on both the theoretical model and the real object.

\section{Literature}

[1] Dhillon B.S.: Reliability, Quality, and Safety for Engineers. CRC PRESS, 2005.

[2] Drozd K.: Modelowanie charakterystyk rozrusznika do silnika wysokoprężnego z komorą wstępną o objętości skokowej $\mathrm{V}_{\mathrm{ss}}=1800 \mathrm{~cm}^{3}$. Praca dyplomowa, Lublin 1994.

[3] Dziubiński M. Plich M.: Modelowanie i symulacja stanów niezdatności układu zasilania elektrycznego pojazdu. XL Zimowa Szkoła Niezawodności „Niezawodność procesów i systemów technicznych". Materiały XL Jubileuszowej Zimowej Szkoły Niezawodności, Szczyrk 2012,

[4] Dziubiński M., Krasowski E.: Plizga K.: Analiza nadmiarowości w rozrusznikach samochodowych. XXXII Zimowa Szkoła Niezawodności „Nadmiarowość w inżynierii i niezawodności". Sekcja Podstaw Eksploatacji Komitetu Budowy Maszyn Polskiej Akademii Nauk, Szczyrk 2004, s. 81-88. 
Modelling and simulation characteristics of starting system

Modelowanie i symulacja charakterystyk obwodu rozruchowego

[5] Dziubiński M., Krasowski E.: Plizga K.: Metody rozpoznawania uszkodzeń rozruszników samochodowych. XXXIII Zimowa Szkoła Niezawodności „Metody badań przyczyn i skutków uszkodzeń". Sekcja Podstaw Eksploatacji Komitetu Budowy Maszyn Polskiej Akademii Nauk, Szczyrk 2005, s.106-117.

[6] Dziubiński M., Ocioszyński J., Walusiak S.: Elektrotechnika i elektronika samochodowa. Wydawnictwa Uczelniane Politechniki Lubelskiej, Lublin 1999.

[7] Filipczyk J., Łazarz B.: Obsługiwanie samochodów w aspekcie zachowania bezpieczeństwa w ruchu drogowym. Redakcja Naukowa Mirosław Siergiejczyk, Problemy Utrzymania Systemów Technicznych, Monografia, Oficyna Wydawnicza Politechniki Warszawskiej, Warszawa 2004, s. 117-131.

[8] Koziej E., Ocioszyński J.: Elektrotechnika samochodowa w pytaniach i odpowiedziach. Wydawnictwo Naukowo-Technicze, Warszawa 1991.

[9] Osowski S.: Modelowanie i symulacja układów i procesów dynamicznych. Oficyna Wydawnicza Politechniki Warszawskiej, Warszawa 2007.

[10] Tylicki H., Zółtowski B.: Urządzenia elektryczne pojazdów samochodowych, Wydawnictwo Piła 2011.

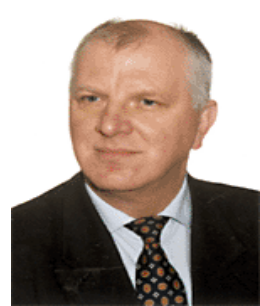

Mieczystaw Dziubiński PhD. Eng. works at the the Mechanical Department of the Faculty of Motor Vehicles at the Lublin University of Technology. In his scientific work he is dealing with diagnostics, electrotechnology and electronics of cars. (Share 50\%).

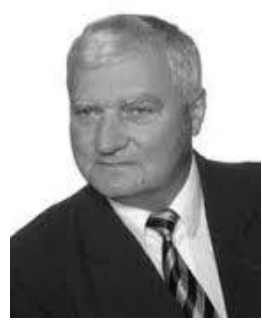

Mieczyslaw Plich PhD. Eng. works at the Department of Informatics and Mechatronics Systems in Transport at the Faculty of Transport at the Warsaw University of Technology. In his scientific work he is dealing with electrical equipment of motor vehicles. (Share 30\%).

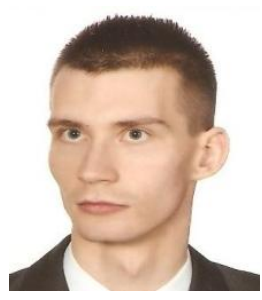

Artur Drozd M.Sc. Eng. graduated from the Transport Faculty at the Lublin University of Technology. At present he is continuing studies to get his doctorate. He is doing research connected with starting systems of motor vehicles. (Share 20\%).

\section{MODELOWANIE I SYMULACJA CHARAKTERYSTYK OBWODU ROZRUCHOWEGO}




\section{Wstęp}

W trakcie eksploatacji samochodów występują problemy identyfikacji uszkodzeń poszczególnych układów. W celu ich określenia prowadzi się badania diagnostyczne z wykorzystaniem systemu OBD - diagnostyka pokładowa oraz szczegółowe pomiary do których należą: pomiar ciśnienia sprężania w cylindrach, pomiar napięcia i natężenia prądu pobieranego przez rozrusznik [7]. W przypadku stwierdzenia niesprawności danego układu przeprowadza się pomiary szczegółowe. Aby przewidzieć stan niesprawności opracowano model: symulacyjny umożliwiający prognozowanie stanu wybranego układu np. elektrycznego oraz przeprowadzono weryfikację na obiekcie rzeczywistym $[1,3,4,5]$. Rozruszniki stanowią niezbędny element silnika samochodowego. Ich bezawaryjna praca wpływa bezpośrednio na prawidłową pracę układu rozruchowego.

Diagnostyka funkcjonalna umożliwia rozpoznanie rodzaju występującego uszkodzenia rozrusznika. Opracowany program służy do wyznaczenia charakterystyk funkcjonalnych rozrusznika. Umożliwia analizę wpływu wybranych uszkodzeń na charakterystyki rozrusznika.

\section{Model niezawodnościowy rozrusznika}

Model teoretyczny został opracowany na podstawie równań układu rozruchowego $[2,6,8,9,10]$. Rysunek 1 przedstawia schemat połączeń obwodu rozruchowego $\mathrm{z}$ zaznaczeniem charakterystycznych wielkości elektrycznych. $\mathrm{Z}$ rysunku wynika, że napięcie $U_{R}$ na zaciskach rozrusznika $\mathrm{w}$ stanie ustalonym można obliczyć sumując spadki napięć (1):

gdzie:

$$
U_{R}=E_{A}-\left(R_{w}+R_{p}\right) I
$$

$E_{A}$ - sita elektromotoryczna akumulatora,

$R_{w}$ - rezystancja wewnętrzna akumulatora,

$R_{p}$ - rezystancja przewodów łączących rozrusznik z akumulatorem,

$I$ - prąd pobierany przez rozrusznik.

Siła przeciwelektromotoryczna wyraża się wzorem (2):

$$
E_{R}=U_{R}-\Delta U_{S Z}-R_{R} \cdot I
$$

Rozpatrując stan pełnego zahamowania $\left(n=0, E_{R}=0\right)$ można określić wartość prądu pobieranego z akumulatora przy rozruchu (prądu zwarcia I) wyrażonego wzorem (3):

$$
I=\frac{E_{A}-\Delta U_{S Z}}{R_{W}+R_{p}+R_{R}}=I_{Z}
$$


Modelling and simulation characteristics of starting system Modelowanie i symulacja charakterystyk obwodu rozruchowego

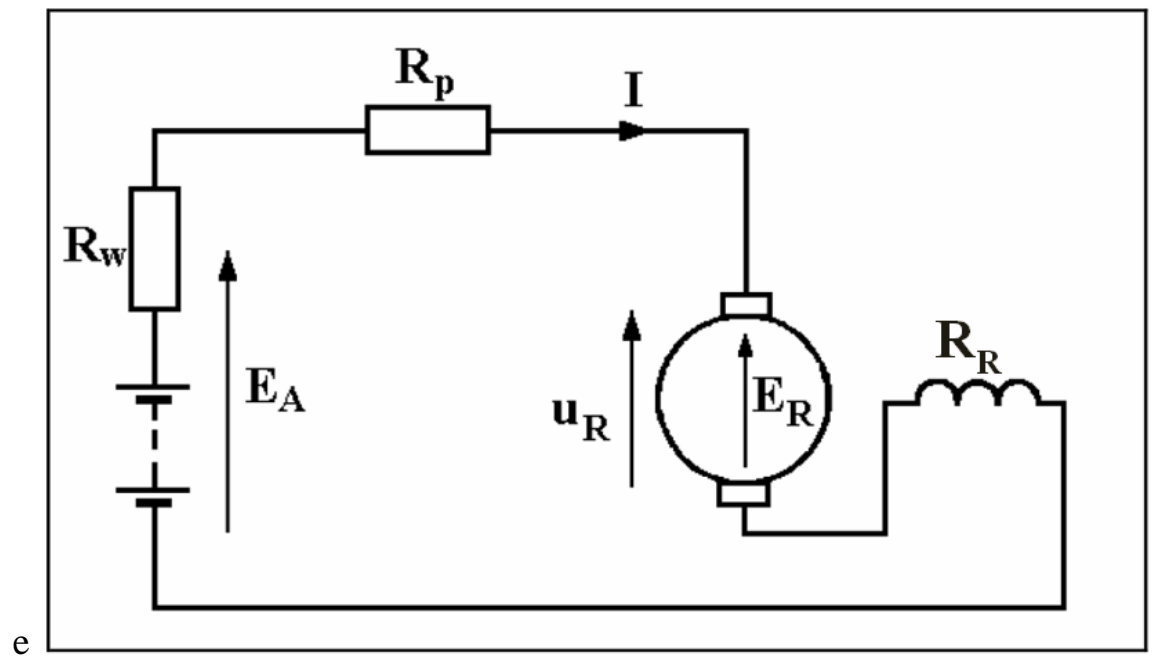

Rys. 1. Schemat połaczeń obwodu rozruchu z zaznaczeniem charakterystycznych wielkości $\left(E_{A}-\right.$ siła elektromotoryczna, $R_{W}$ - rezystancja wewnętrzna akumulatora, $R_{p}$ - rezystancja przewodów, $U_{R}-$ napięcie na rozrusznik,

$E_{R}$ - sila przeciwelektromotoryczna, $R_{R}$ - rezystancja rozrusznika)

Moc rozrusznika $P_{e}$ wyraża się wzorem (4):

$$
P_{e}=E_{R} I=\left(E_{A}-\Delta U_{S Z}\right) I-\left(R_{w}+R_{p}+R_{R}\right) I^{2}
$$

Wartość mocy równa się zero w dwóch punktach: w punkcie początkowym (przy $\left.E_{R}=0 \quad i n=0\right)$ oraz w punkcie pracy odpowiadającym teoretycznemu stanowi jałowemu $(I=0)$.

Prąd, przy którym moc elektromagnetyczna osiąga maksymalną wartość, wyznacza się z zależności (5):

$$
I_{p \max }=\frac{E_{A}-\Delta U_{S Z}}{2\left(R_{w}+R_{p}+R_{R}\right)}=\frac{I_{z}}{2}
$$

Moc maksymalną rozrusznika wyznacza się, podstawiając do zależności (4) prąd ze wzoru (5):

$$
P_{\text {max }}=\frac{\left(E_{A}-\Delta U_{S Z}\right)^{2}}{4\left(R_{w}+R_{p}+R_{R}\right)}
$$

Sprawność elektromagnetyczną rozrusznika przyjmuje się - $\eta_{e}=0,85-0,9$ - wzór 7

$$
P_{R}=P_{e} \eta_{e}
$$

Zestawienie modelowanych charakterystyk rozrusznika przedstawia rys.2. 


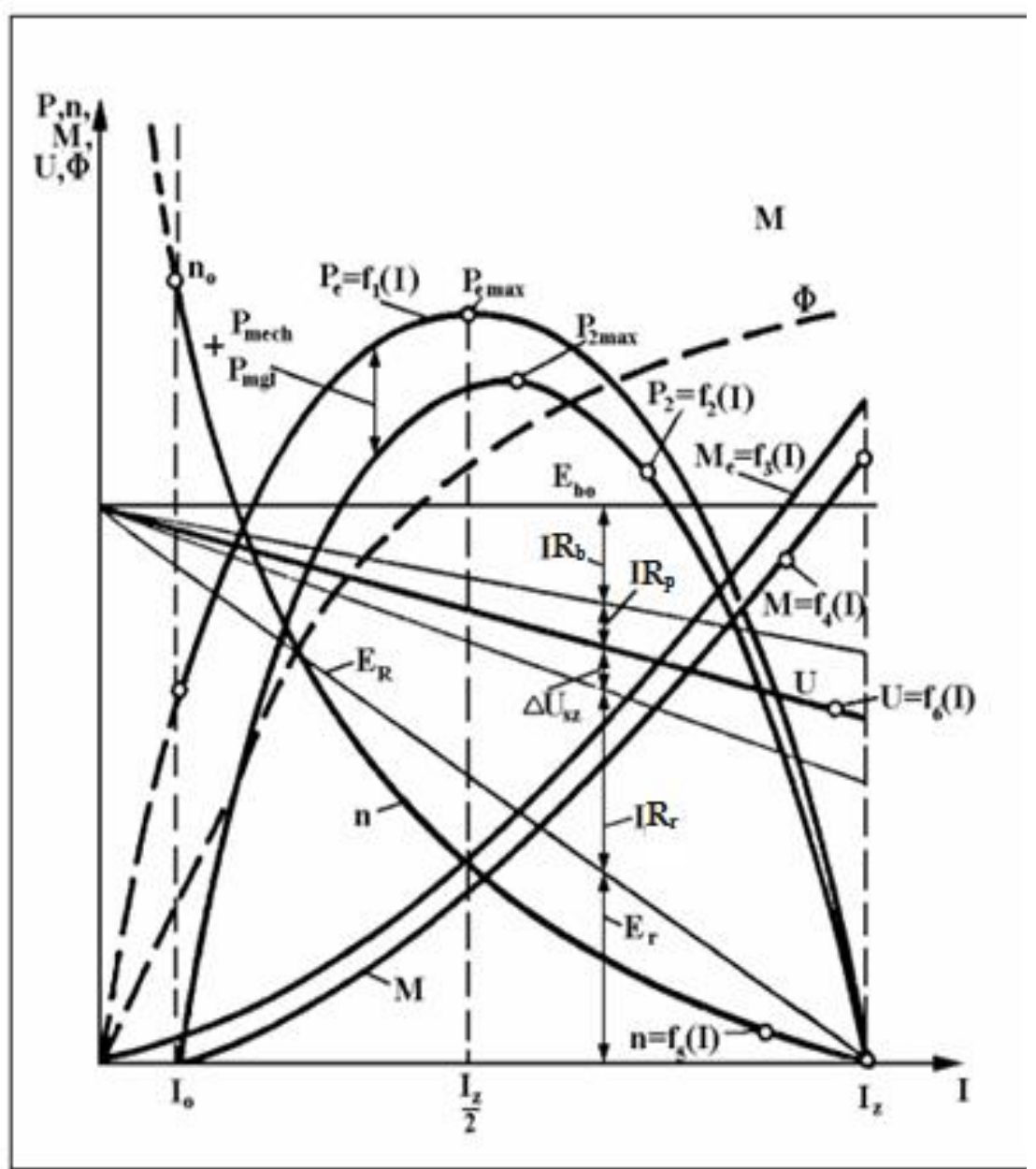

Rys. 2. Charakterystyki rozrusnika samochodwego ( $P$ - moc, $n$ - prędkość obrotowa, $M$ - moment rozrusznika, $U$ - napięcie, $\phi$ - strumień magnetyczny, $E_{R}$ - sila przeciwelektrootoryczna rozrusznika, $I_{Z}$ - prąd zwarciowy)

Aby przeanalizować wpływ uszkodzeń na charakterystyki funkcjonalne rozruszników, należy przeprowadzić obliczenia, dokonując wyboru typu rozrusznika, materiału bieguna i jarzma, materiału blachy wirnika oraz rodzaju uszkodzenia (rys.3) oraz wprowadzając podstawowe dane rozrusznika zgodnie z rys. 4. Program dla wybranego rodzaju uszkodzenia wyznacza charakterystyki dla sprawnego rozrusznika, a także dla danego rodzaju uszkodzenia na jednym wykresie (rys.5). 
Modelling and simulation characteristics of starting system Modelowanie i symulacja charakterystyk obwodu rozruchowego

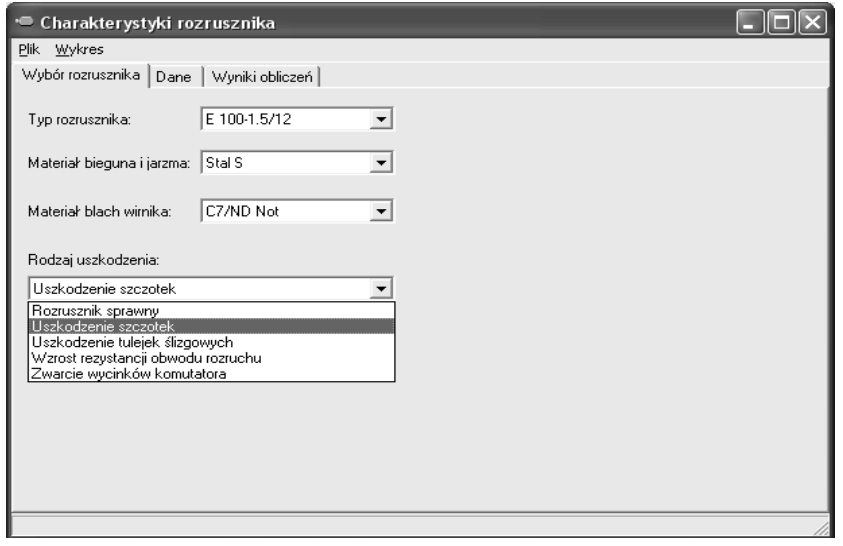

Rys.3. Wybór podstawowych funkcji programu

\begin{tabular}{|c|c|c|c|c|c|c|c|c|}
\hline \multicolumn{7}{|c|}{ Charakterystyki rozrusznika } & \multicolumn{2}{|c|}{ - 0 区 } \\
\hline \multirow{3}{*}{\multicolumn{9}{|c|}{$\begin{array}{l}\text { Plik Wykres } \\
\text { Wybór rozrusznika [Dane] | Wyniki obliczeń| } \\
\text { Rozrusznik | }\end{array}$}} \\
\hline & & & & & & & & \\
\hline & & & & & & & & \\
\hline$P n=1500$ & {$[\mathrm{~W}]$} & $\mathrm{l}=\sqrt{0,083}[\mathrm{m]}$ & $\mathrm{bb}=0,025$ & {$[\mathrm{~m}]$} & kteta $=1,22$ & {$[-]$} & aes $=2$ & {$[-]$} \\
\hline $\mathrm{U}=12$ & $\mathrm{M}]$ & $\mathrm{bPr}=\sqrt[0.0018]{[\mathrm{m}]}$ & $h b=0,0068$ & & $D k=0.0405$ & [m] & & \\
\hline Qbat $=60$ & [Ah] & $\mathrm{hPr}=\sqrt{0.0036}[\mathrm{~m}]$ & $\mathrm{db}=0.08$ & {$[\mathrm{~m}]$} & Lkom $=\sqrt{0.0229}$ & {$[\mathrm{~m}]$} & & \\
\hline etaz $=0.6$ & {$[-]$} & $\left.h z l={ }_{0.0099}^{[m]}\right]$ & $\mathrm{b} n=0,037$ & {$[\mathrm{~m}]$} & bszzz $=0,0007$ & {$[\mathrm{~m}]$} & & \\
\hline $\mathrm{Rp}=0.001$ & {$[\mathrm{Ohm}]$} & bozl $=\longdiv { 0 . 0 0 1 5 } [ \mathrm { m } ]$ & $h n=0,0032$ & {$[\mathrm{~m}]$} & $h s z c z=\sqrt[0.02]{0.02}$ & {$[\mathrm{~m}]$} & & \\
\hline Bdel $=0.65$ & [T] & hozl= $=0,0006[\mathrm{~m}]$ & $D_{n}=0.0678$ & [m] & $\mathrm{s} z z \mathrm{cz}=\sqrt{0,016}$ & {$[\mathrm{~m}]$} & & \\
\hline $\mathrm{kFe}=0.97$ & {$[-1]$} & $\mathrm{hz}=\sqrt[0.0099]{[\mathrm{m}]}$ & Ibuw $=0,0835$ & {$[\mathrm{~m}]$} & deltai $=\sqrt{4 E-5}$ & [m] & & \\
\hline$P=2$ & {$[-]$} & bzl= $=0.0032[\mathrm{~m}]$ & bbuw $=0.025$ & {$[\mathrm{~m}]$} & pnsz $=\sqrt{40000}$ & {$[\mathrm{~N} / \mathrm{m}]$} & & \\
\hline$a=$ & {$[-1$} & $\mathrm{r} 1=\sqrt{0,0016}[\mathrm{~m}]$ & $\mathrm{bu}=0,0175$ & {$[\mathrm{~m}]$} & mit $=0.2$ & {$[-]$} & & \\
\hline 0.0673 & {$[\mathrm{~m}]$} & $D_{i \mathrm{WW}}=\sqrt{0,087}[\mathrm{~m}]$ & $r u=0.0015$ & {$[\mathrm{~m}]$} & $k 1=3 E-5$ & {$[-]$} & & \\
\hline Zlob $=31$ & {$[-]$} & $\mathrm{hi}=0.007[\mathrm{~m}]$ & $h u=0.0075$ & {$[\mathrm{~m}]$} & $\mathrm{Dl}=\sqrt{0.0165}$ & {$[\mathrm{~m}]$} & & \\
\hline 31 & {$[-]$} & $\mathrm{bi}=\sqrt{0,131}[\mathrm{~m}]$ & $\mathrm{d} U_{\mathrm{s}}=0.3$ & $\mathrm{M}]$ & $\mathrm{bPu}=\sqrt{0.0014}$ & {$[\mathrm{~m}]$} & & \\
\hline$N=62$ & 1-1 & $D_{w}=0.0223 \mathrm{Im}$ & $z u w=10$ & 1.1 & $\mathrm{dP}=\sqrt{0.002}$ & Iml & & \\
\hline
\end{tabular}

Rys.4. Podstawowe dane rozrusznika E100.

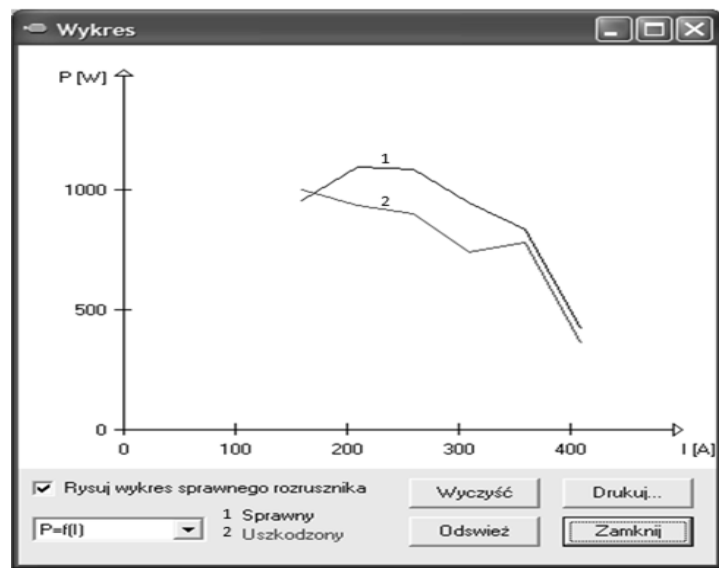

Rys.5. Charakterystyka $P=f(I)$ przy uszkodzeniu szczotek (1-sprawny, 2-uszkodzony) 


\section{Badania symulacyjne uszkodzeń zrealizowane na obiekcie rzeczywistym.}

Badania zrealizowano na stanowisku badawczym firmy Bosch EFAL 50A/5, które umożliwia przeprowadzenie procesu hamowania rozrusznika oraz rejestrację: prądu pobieranego przez rozrusznik, spadku napięcia podczas rozruchu, prądu pobieranego przez rozrusznik przy hamowaniu, spadku napięcia podczas hamowania, prędkości obrotowej rozrusznika oraz momentu obrotowego rozrusznika. Rejestrację wyników przeprowadzono z wykorzystaniem aparatury Adlink Technology Inc. USB-1900 Series z oprogramowaniem LabView (rys.7)

$\mathrm{Na}$ stanowisku badawczym (rys.6.) zasymulowano następujące uszkodzenia w obwodzie rozruchowym:

- Uszkodzenie 1: brak połączenia pomiędzy uzwojeniem wzbudzenia, a pierwszą szczotką dodatnią

- Uszkodzenie 2: brak połączenia pomiędzy uzwojeniem wzbudzenia, a drugą szczotką dodatnią

- Uszkodzenie 3: przerwa w uzwojeniu wzbudzenia i uzwojeniu bocznikowym

- Uszkodzenie 4: uszkodzenie uzwojenia bocznikowego

- Uszkodzenie 5: brak połączenia masy ze szczotką ujemną

- Uszkodzenie 6: zwarcie pomiędzy wycinkami komutatora

- Uszkodzenie 7: zwarcie dwóch par wycinków komutatora

- Uszkodzenie 8: rozładowanie akumulatora

- Uszkodzenie 9: nadmierny luz w tulei ślizgowej tarczy

- Uszkodzenie 10: nadmierny luz w tulei ślizgowej głowicy

- Uszkodzenie 11: odłączony jeden zwój od komutatora wirnika

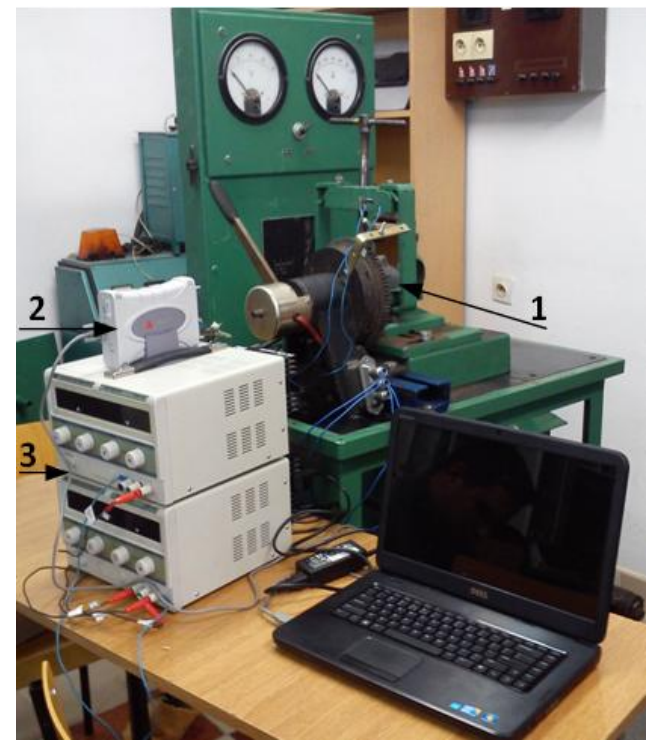

Rys.6. Stanowisko do badań stanów nieustalonych układów rozruchowych (1-badany rozrusznik, 2- przetwornik, 3-zasilacze) 
Modelling and simulation characteristics of starting system Modelowanie i symulacja charakterystyk obwodu rozruchowego

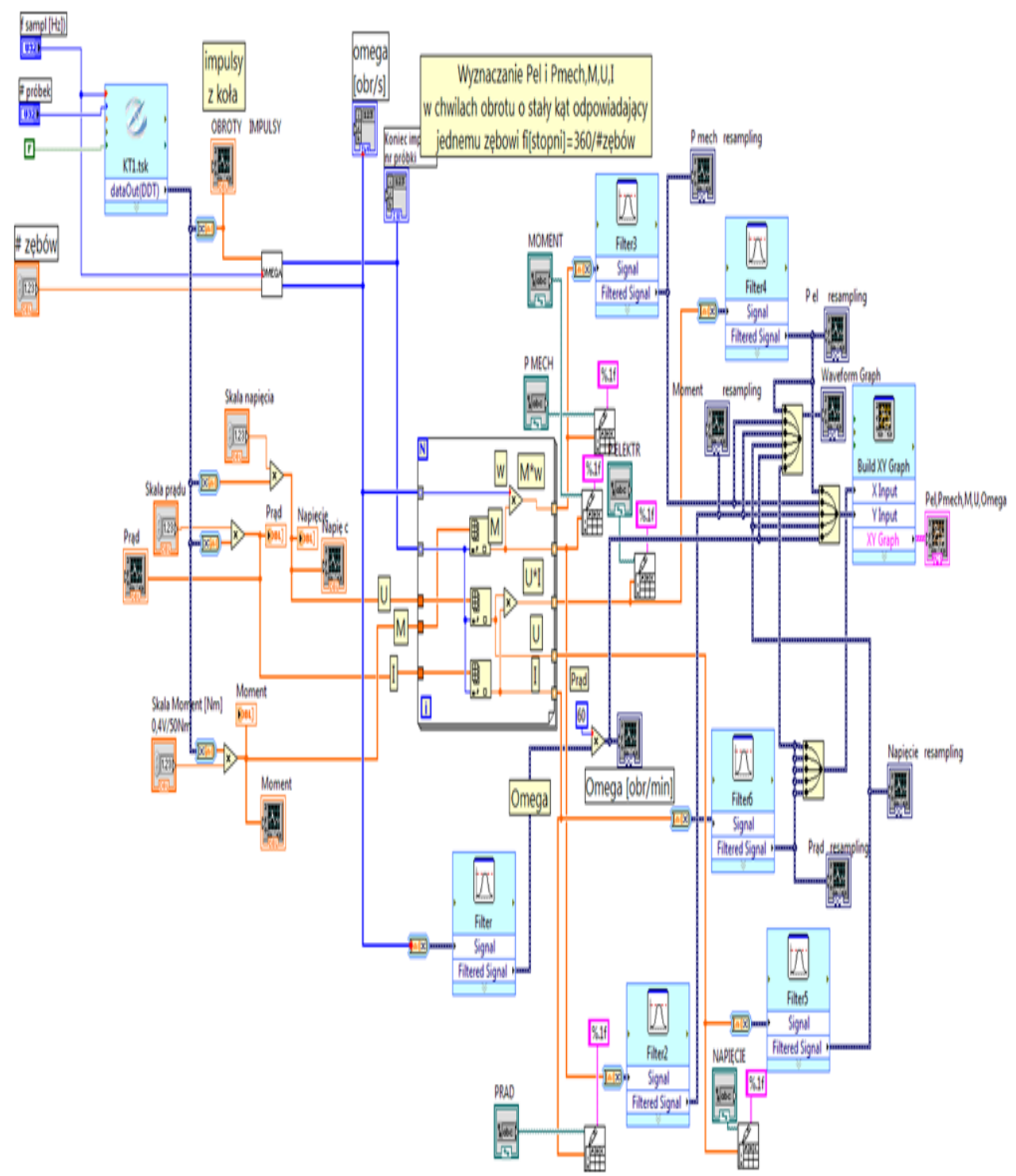

Rys.7. Schemat algorytmu do wyznaczania charakterystyk rozrusznika.

Na rys. 8 oraz rys. 9 przedstawiono przebiegi prądu oraz napięcia w funkcji czasu dla wybranych uszkodzeń. Uszkodzenia zostały zasymulowane poprzez odłączenie końcówki od szczotki „,". Z rysunku nr 8 wynika, że maksymalna wartość prądu wynosi 655 A, i była niższa od wartości prądu dla rozrusznika prawidłowo działającego. W końcowej fazie rozruchu, tj. po upływie $107 \mathrm{~ms}$, rozrusznik osiągnął wartość prądu 378 A, co oznacza wzrost wartości prądu o 50\% w stosunku do sprawnego rozrusznika. 


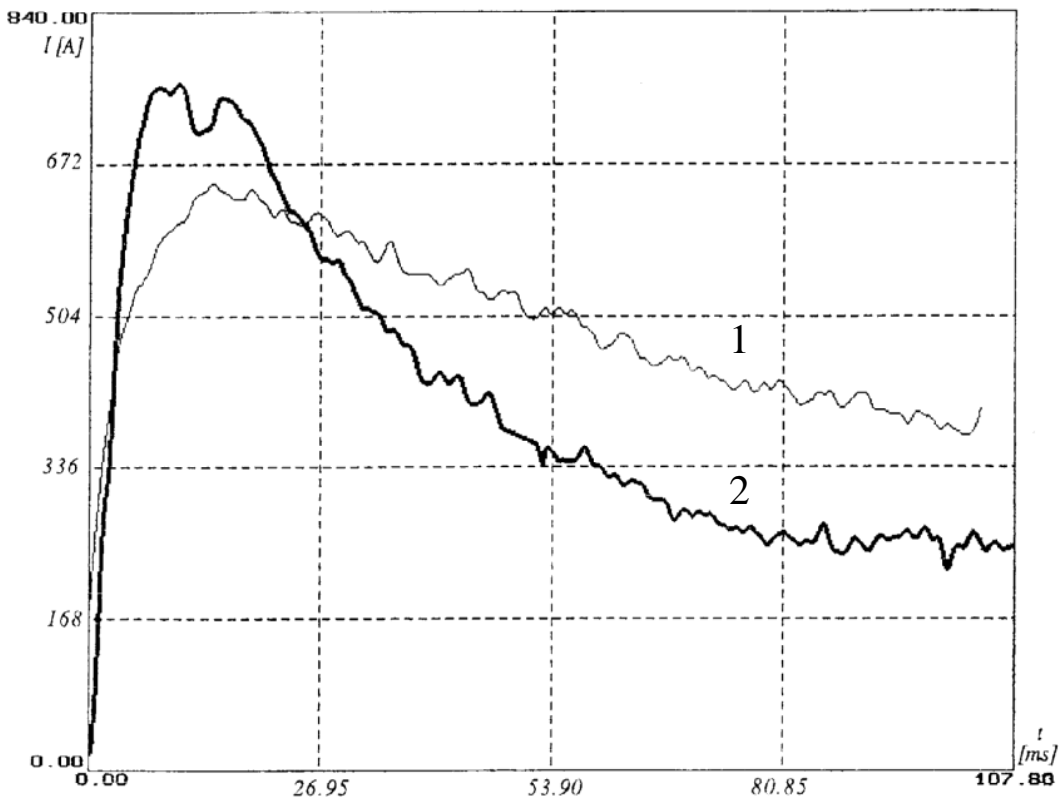

Rys. 8. Charakterystyka $I=f(t)$ przy odtaczonym uzwojeniu wzbudzenia od pierwszej szczotki dodatniej (1- uszkodzony, 2- sprawny)

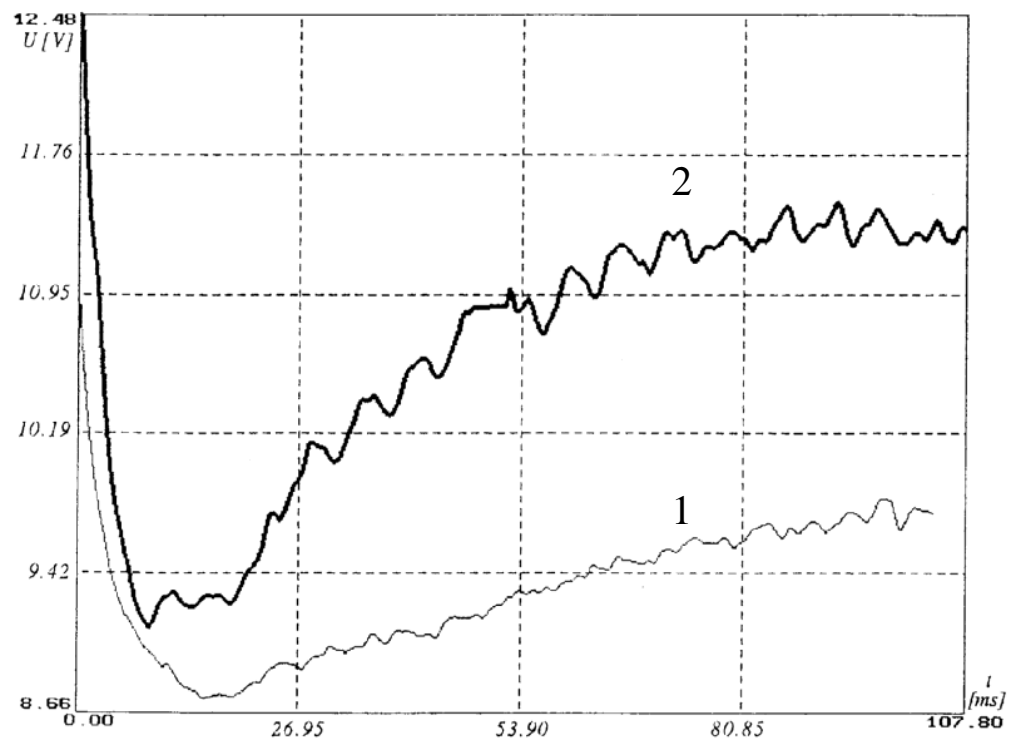

Rys. 9. Charakterystyka $U=f(t)$ przy odtaczonym uzwojeniu wzbudzenia od pierwszej szczotki dodatniej (1 - uszkodzony, 2 - sprawny) 
Modelling and simulation characteristics of starting system Modelowanie i symulacja charakterystyk obwodu rozruchowego

$\mathrm{Na}$ rysunku $\mathrm{nr} 10$ przedstawiono charakterystykę symulowanego uszkodzenia w postaci braku połączenia pomiędzy uzwojeniem wzbudzenia, a pierwszą szczotką dodatnią. Z rysunku wynika, że przy uszkodzeniu moc rozrusznika jest znacznie mniejsza niż przy sprawnie działającym.

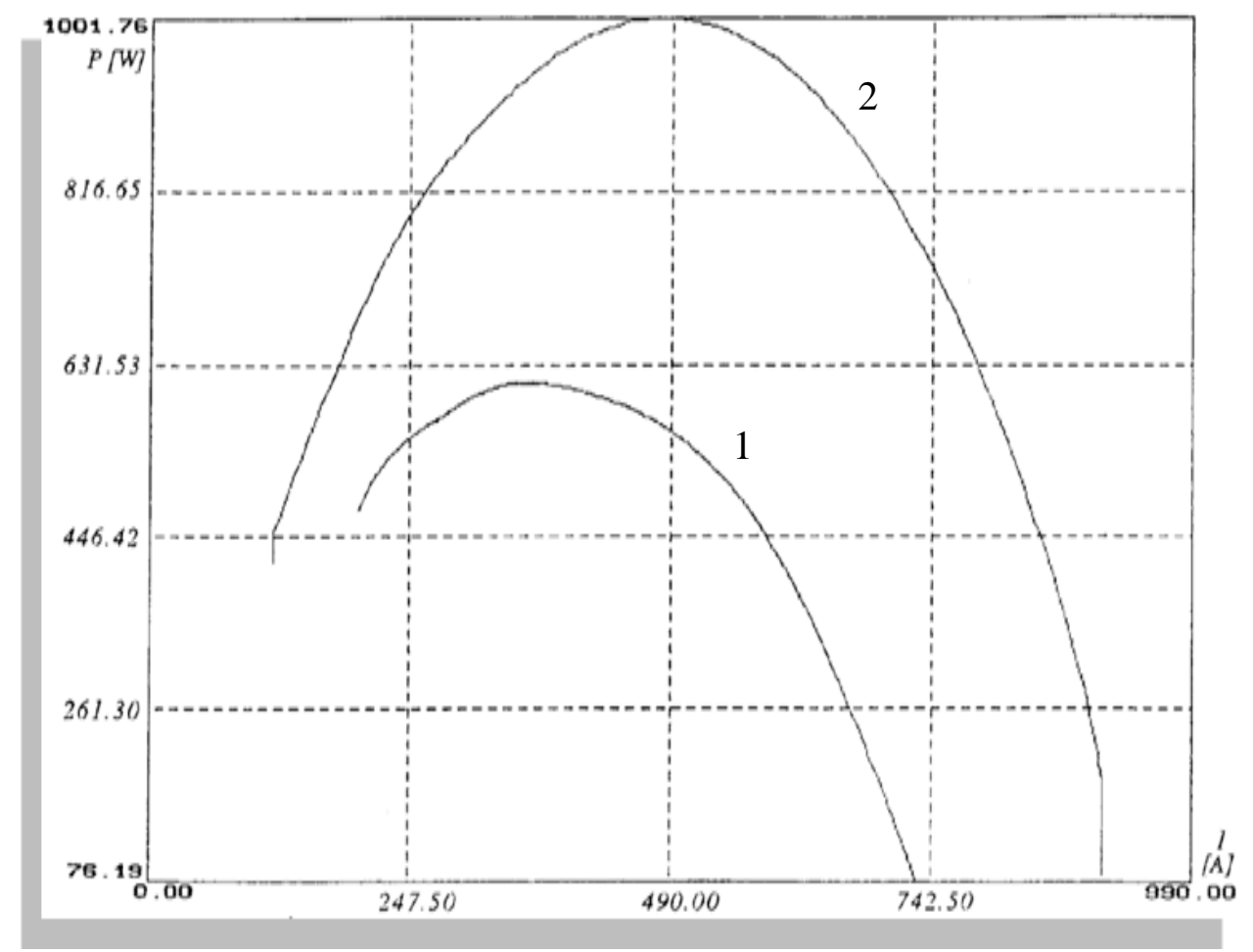

Rys. 10. Funkcja $P=f(I)$ przy braku połaczenia uzwojenia wzbudzenia z pierwsza szczotka dodatnia (1 - uszkodzony, 2 - sprawny)

\section{Podsumowanie}

Opracowany model rozrusznika umożliwia symulowanie charakterystyk obwodu elektrycznego rozrusznika dla różnych uszkodzeń. Zarejestrowane wyniki i sygnały umożliwiają analizowanie wpływu poszczególnych uszkodzeń na parametry funkcjonalne układu rozruchu. Na podstawie przeprowadzonych badań można stwierdzić, że otrzymane podczas eksperymentu charakterystyki prądu i napięcia odzwierciedlają charakterystyki zasymulowane $\mathrm{w}$ modelu matematycznym. Opracowany model oraz przeprowadzone badania weryfikacyjne na obiekcie rzeczywistym umożliwiają prognozowanie stanu technicznego rozrusznika. 
Określenie rodzaju uszkodzenia dokonuje się poprzez porównanie charakterystyk mocy dla danego uszkodzenia $\mathrm{z}$ mocą maksymalną rozwijaną przez sprawny rozrusznik. Przy uszkodzeniu w postaci braku połączenia pomiędzy uzwojeniem wzbudzenia, a pierwszą szczotką dodatnią moc jest mniejsza o $60 \%$ w porównaniu z mocą rozrusznika sprawnego. Opracowana metoda analizy niezawodnościowej rozruszników jest oparta na modelu teoretycznym i obiekcie rzeczywistym.

\section{Literatura}

[1] Dhillon B.S.: Reliability, Quality, and Safety for Engineers. CRC PRESS, 2005.

[2] Drozd K.: Modelowanie charakterystyk rozrusznika do silnika wysokoprężnego $\mathrm{z}$ komorą wstępną o objętości skokowej $\mathrm{V}_{\mathrm{ss}}=1800 \mathrm{~cm}^{3}$. Praca dyplomowa, Lublin 1994.

[3] Dziubiński M. Plich M.: Modelowanie i symulacja stanów niezdatności układu zasilania elektrycznego pojazdu. XL Zimowa Szkoła Niezawodności „Niezawodność procesów i systemów technicznych". Materiały XL Jubileuszowej Zimowej Szkoły Niezawodności, Szczyrk 2012, s.

[4] Dziubiński M., Krasowski E.: Plizga K.: Analiza nadmiarowości w rozrusznikach samochodowych. XXXII Zimowa Szkoła Niezawodności „ Nadmiarowość w inżynierii i niezawodności". Sekcja Podstaw Eksploatacji Komitetu Budowy Maszyn Polskiej Akademii Nauk, Szczyrk 2004, s. 81-88.

[5] Dziubiński M., Krasowski E.: Plizga K.: Metody rozpoznawania uszkodzeń rozruszników samochodowych. XXXIII Zimowa Szkoła Niezawodności „Metody badań przyczyn i skutków uszkodzeń". Sekcja Podstaw Eksploatacji Komitetu Budowy Maszyn Polskiej Akademii Nauk, Szczyrk 2005, s.106-117.

[6] Dziubiński M., Ocioszyński J., Walusiak S.: Elektrotechnika i elektronika samochodowa. Wydawnictwa Uczelniane Politechniki Lubelskiej, Lublin 1999.

[7] Filipczyk J., Łazarz B.: Obsługiwanie samochodów w aspekcie zachowania bezpieczeństwa w ruchu drogowym. Redakcja Naukowa Mirosław Siergiejczyk, Problemy Utrzymania Systemów Technicznych, Monografia, Oficyna Wydawnicza Politechniki Warszawskiej, Warszawa 2004, s. 117-131.

[8] Koziej E., Ocioszyński J.: Elektrotechnika samochodowa w pytaniach i odpowiedziach. Wydawnictwo Naukowo-Technicze, Warszawa 1991.

[9] Osowski S.: Modelowanie i symulacja układów i procesów dynamicznych. Oficyna Wydawnicza Politechniki Warszawskiej, Warszawa 2007.

[10] Tylicki H., Zółtowski B.: Urządzenia elektryczne pojazdów samochodowych, Wydawnictwo Piła 2011. 
Modelling and simulation characteristics of starting system Modelowanie i symulacja charakterystyk obwodu rozruchowego

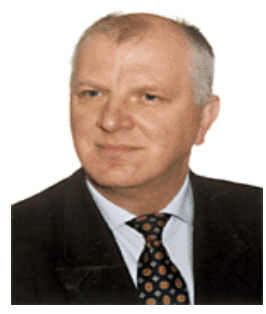

Dr inż. Mieczyslaw Dziubiński pracuje w Katedrze Pojazdów Samochodowych na Wydziale Mechanicznym Politechniki Lubelskiej. W swojej pracy naukowej zajmuje się diagnostyka, elektrotechnika i elektronika samochodowa. (Udziat 50\%).

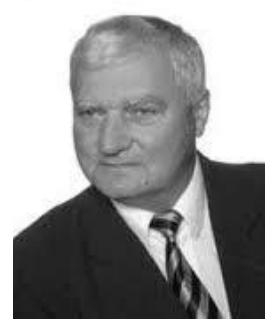

Dr inz. Mieczyslaw Plich pracuje w Zakladzie Systemów Informatycznych i Mechatronicznych $w$ Transporcie na Wydziale Transportu Politechniki Warszawskiej. W swojej pracy pracy naukowej zajmuje się głównie tematyka zwiazana z elektrycznym wyposażeniem pojazdów samochodowych. (Udziat 30\%).

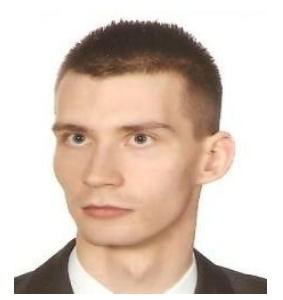

Mgr inz. Artur Drozd ukończyt kierunek Transport na Politechnice Lubelskiej. Obecnie kontynuuje nauke studiach doktoranckich. Prowadzi badania zwiazane $z$ uktadem rozruchowym pojazdów samochodowych. (Udziat 20\%). 